\title{
Pedagogisk utdanning for helsepersonell
}

\author{
Norge mangler et helhetlig pedagogisk utdanningsprogram for helsepersonell som skal undervise \\ ved universiteter og høyskoler og i utdanningen av spesialister.
}

Publisert først på nett 5.3. 2012

Helsefagutdanningene ved høyskolene har ikke alltid forventet effekt for studentenes forberedelse til sitt yrke (1). Dette gjelder antakelig også helsefagutdanningene ved universitetene, blant annen medisin. Det er nødvendig å ta en diskusjon om dette, og saken må tas på alvor av Helsedirektoratet og universitetene. I Norge mangler vi fremdeles et helhetlig pedagogisk utdanningsprogram som ivaretar alle sidene av studiene i medisin og helsefag.

For å kunne utdanne helsefaglig personell kreves det kompetanse innen programutvikling, studieplanlegging, undervisning og evaluering (både av studenter og studieprogrammer). Det er viktig å sikre at de som skal undervise helsepersonell, skaper effektive pedagogiske programmer som resulterer i helsetjenester av høy kvalitet.

\section{Masterstudiet i Maastricht}

Masterstudiet i Health Professions Education (MHPE) ved universitetet i Maastricht i Nederland er et av flere slike utdanningstilbud som gir deltakerne den kunnskap og de ferdigheter som er nødvendig for en karriere innen medisinsk og helsefaglig utdanning og forskning. Liknende helsepedagogiske studier er etablert i USA, Canada og Storbritannia samt i Sverige og Danmark. MHPE-studiet i Nederland er et toårig program med undervisning på engelsk. Det er i stor grad basert på fjernundervisning, med tre korte perioder på campus i Maastricht. Gjennomført og bestått studium gir graden master of science in health professions education.

Campusbaserte enheter er spesielt beregnet for ferdighetstrening, kunnskapsog problembasert læring og for å bli kjent med de andre studentene. Studiesamlingene er også ment å gi en innføring i innholdet i de enhetene som studentene skal arbeide med hjemmefra. Det legges sterk vekt på praktiske øvelser, ettersom evnen til å anvende tilegnet kunnskap er av avgjørende betydning. Studentene kan dermed bruke sin nyvunne innsikt i sin egen arbeidssituasjon.

I fjernundervisningsbolkene arbeider studentene med mappeoppgaver, enten individuelt eller i samarbeid med andre. En elektronisk læringsportal med tilgang til universitetsbibliotekets egne databaser, bøker og tidsskrifter er en forutsetning for deltakelse i programmet.

Studiet dekker blant annet kognitive læringsprosesser, programdesign (curriculum design), instruksjon, læringsmiljø, evaluering og kvalitetssikring av studieprogrammer samt organisasjons- og kunnskapsledelse og akademiske forskningsferdigheter, med kvalitative og kvantitative forskningsmetoder innen helsepedagogikk. I siste semester skrives en forskningsbasert masteroppgave.

Studiet innebærer stor arbeidsbelastning, stipulert til minst 20 studietimer per uke, med faste, forhåndsbestemte innleveringsdatoer. Disse bør følges for at man skal unngå å bli akterutseilt. Det kreves derfor motivasjon, stor egeninnsats og støtte fra omgivelsene for å lykkes med studiet.

Alle bolkene er logisk bygd opp, og for å kunne besvare oppgavene må man lese både pensum og en god del tilleggslitteratur. Det gis karakter på oppgavebesvarelsene på en skala fra 5 til 10, der 10 er fremragende. Deler av studiet bør gjennomføres på heltid. Masteroppgaven kan skrives under en overlegepermisjon. Den totale studieavgiften er på rundt 14000 euro, i tillegg kommer utgifter til bøker, reise og opphold.

\section{Veiledning av leger under spesialisering}

Undertegnede gjennomførte MHPE-studiet i 2009-11 og skrev masteroppgave om veiledning av leger i spesialisering (2). Veiledningen er ment å bygge bro mellom teoretisk og praktisk læring og skal være tilpasset spesialistkandidatenes læringsbehov og profesjonelle interesser i den kliniske hverdag. Gode resultater i klinisk utdanning er relatert til effektiv veiledning fra veilederne i praksisfeltet. Systematisk veiledning bør være en sentral komponent i spesialistutdanningen. Dessverre er veiledningen ofte tilfeldig og lite tilfredsstillende.

Sju leger under spesialisttjeneste ved en norsk barneklinikk ble valgt ut. Inklusjonskriteriene var minimum tre år klinisk erfaring og gjennomført rotasjon på seks måneder i nyfødtintensivavdelingen. En kvalitativ fenomenologisk tilnærming ble benyttet. Det ble utført individuelle semistrukturerte intervjuer, som ble tatt opp på lydspor og deretter transkribert. Respondentenes utsagn om opplevde erfaringer ble samlet og viste hvilken betydning veiledningen hadde for dem. Temaer som ble identifisert som relevante, ble klassifisert i en matrise (3). Tolkingene ble i tillegg analysert av en annen, uavhengig person med fagpedagogisk utdanning. Den endelige matrisen tjente som ramme for å besvare forskningsspørsmål og var en verdifull referanse for analysene.

Studien viste at det var en signifikantforskjell mellom legenes forventninger og erfaringer og for svak struktur i veiledningen. Anvendelse av forskningsbasert kunnskap og hjelp til refleksjon i klinisk praksis viste seg å være lavt prioritert. Legene mente at det var liten sammenheng mellom veiledningen og kravet om sikker praksis og kvalitet i tjenesten. De ønsket at veiledere skal ta et større ansvar for oppfølgingen av spesialistkandidatene og for å tilrettelegge for læring i avdelingen. Veiledere bør få muligheter til å utvikle sine pedagogiske ferdigheter. Legene ønsket bedre struktur og planlegging av veiledningen og etterspurte stimulering til reflektiv læring, der teori knyttes til klinisk praksis. Forholdet mellom teorikurs og plassering i tjenesterotasjon må bli bedre og veiledningen må tilpasses bedre til kandidatenes utdanningsnivå og erfaring. Legene foreslo bl.a. å innføre sjekklister for å kvalitetssikre måloppnåelsen.

\section{Stefan Kutzsche}

stefan.kutzsche@medisin.uio.no

Barneklinikken

Oslo universitetssykehus, Ullevål

Stefan Kutzsche (f. 1954) er ph.d., m.ha.,

m.sc. (MHPE), spesialist i barnesykdommer og i anestesiologi og overlege ved nyfødtintensivavdelingen ved Oslo universitetssykehus, Ullevål. Han er redaktør av Paidos, tidsskriftet til Norsk barnelegeforening, og medlem i spesialistkomiteen for pediatri.

Forfatter har fylt ut ICMJE-skjemaet og oppgir ingen interessekonflikter

Litteratur

1. Smebye JC. Virker utdanningen? Aftenposten 25.1.2012.

2. Kutzsche S. A lifeworld study of supervision in paediatric postgraduate training. Masteravhandling. Maastricht: Maastricht University, 2011.

3. King N. Template analysis. I: Symon G, Cassell C red. Qualitative methods and analysis in organizational research. London: Sage, 1998. 